\title{
PEMBINAAN TERHADAP NARAPIDANA PENGGUNA NARKOTIKA DI LEMBAGA PEMASYARAKATAN NARKOTIKA KELAS II A JAKARTA
}

\section{Dewi Linarsih ${ }^{1}$; Muhammad Khemal Andhika ${ }^{2}$}

1Politeknik Ilmu Pemasyarakatan, $\underline{\text { linarsihdewi@gmail.com }}$

${ }^{1}$ Politeknik Ilmu Pemasyarakatan

\begin{abstract}
Law in Indonesia is now developing following a variety of human needs. The development of this law was also followed by the development of the prison system into a correctional system based on Pancasila and the 1945 Constitution. The change was made because the prison system only prioritizes the element of revenge and imprisonment only, so that the human rights of inmates are not taken into account. The type of research used in this study is a descriptive type of research. Based on the research that has been conducted the Implementation of Inmate Development in Narcotics Correctional Institution Class IIA Jakarta The implementation of coaching of inmates is stipulated in Article 7 of Government Regulation No. 31 of 1999 concerning The Construction and Mentoring of Community Correctional Officers.
\end{abstract}

\section{ARTICLE INFO}

\section{Keywords:}

Coaching; narcoticsinmates; correctional

\section{Cite this paper:}

Dewi Linarsih, M. K. (2021).

Pembinaan Terhadap

Narapidana Pengguna

Narkotika Di Lembaga

Pemasyarakatan Narkotika

Kelas II A Jakarta. Widya

Yuridika: Jurnal Hukum.

Scope Article

Law and Society

\section{PENDAHULUAN}

Hukum di Indonesia kini berkembang mengikuti berbagai macam kebutuhan manusia. Perkembangan hukum ini juga diikuti dengan berkembangnya sistem kepenjaraan menjadi sistem pemasyarakatan yang berlandaskan Pancasila dan Undang-Undang Dasar 1945. Perubahan itu dilakukan karena sistem kepenjaraan hanya mengutamakan unsur balas dendam dan pejeraan saja, sehingga hak asasi narapidana tidak diperhatikan. Perkembangan sistem kepenjaraan ini dimaksudkan agar dapat mendukung pembangunan nasional di Indonesia, yang dimana pembangunan di era reformasi telah dilaksanakan oleh pemerintah dengan mengikutsertakan seluruh lapisan masyarakat, oleh karena itu agar pelaksanaan pembangunan di Indonesia dapat berjalan dengan lancer, maka haruslah diselamatkan dari gangguan dari para pelaku kejahatan, agar masyarakat merasa aman dan tentram (Jainah, 2015) Maka dari itu sistem pemasyarakatan dijadikan sebagai dasar dalam pelaksanaan pemidanaan di Indonesia dengan unsur filosofis reintegrasi sosial yang memiliki asumsi bahwa kejahatan itu merupakan konflik yang terjadi antara narapidana dengan masyarakat, sehingga pemidanaan ditujukkan untuk memulihkan konflik atau menyatukan kembali narapidana dengan masyarakat (reintegrasi) (Dwiatmodjo, 2014). 
Sistem pemasyarakatan ini kemudian diatur dalam Undang-Undang No. 12 tahun 1995 tentang pemasyarakatan.

Dalam UndangUndang No. 12 tahun 1995 dijelaskan bahwa Lembaga Pemasyarakatan (Lapas) merupakan institusi dari sub sistem peradilan pidana dengan fungsi strategis sebagai pelaksana pidana penjara dan sebagai tempat untuk melakukan pembinaan bagi narapidana. Berdasarkan Keputusan Menteri Kehakiman Republik Indonesia No. 02- PK.04.10 Tahun 1990 tentang Pola Pembinaan Narapidana/Tahanan, Lembaga Pemasyarakatan dalam Sistem Pemasyarakatan merupakan tempat untuk mendidik dan membina narapidana serta berperan penting dalam pembangunan nasional. Dalam melakukan pembinaan Lapas melakukan beberapa pengklasifikasian yang digolongkan berdasarkan (Pasal 11 ayat (1) UU No. 12 tahun 1995) :

a. Umur;

b. Jenis Kelamin;

c. Lama pidana yang dijatuhkan;

d. Jenis Kejahatan;

e. Kriteria lainnya sesuai dengan kebutuhan atau perkembangan pembinaan Pengklasifikasian tersebut salah satunya adalah berdasarkan jenis kejahatan yang dilakukan oleh narapidana tersebut.

Dalam hal ini salah satu yang menjadi fokus yaitu pelaku kejahatan Narkotika yang merupakan salah satu kejahatan yang termasuk Extraordinary Crime. Perlu diperhatikan pula bahwa pelaku kejahatan narkoba itu juga dapat di klasifikasikan lagi menjadi bandar, pengedar, dan pengguna/pecandu. Berdasrkan pasal 35 UU No. 35 tahun 2009 tentang Narkotika, menjelaskan yang dimaksud pengedar merupakan orang yang melakukan kegiatan menyalurkan atau menyerahkan narkotika, baik dalam rangka perdagangan, bukan perdagangan maupun pemindahtangan, untuk kepentingan pelayanan kesehatan dan pengembangan ilmu pengetahuan dan teknologi. Sedangkan Pengguna menurut UU No. 35 tahun 2009 pasal 1 angka 13, yaitu orang yang menggunakan atau menyalahgunakan Narkotika dan dalam keadaan ketergantungan pada Narkotika, baik secara fisik maupun psikis. Kemudian pada pasal 1 angka 15 UU No. 35 tahun 2009 juga dijelaskan bahwa Penyalah Guna adalah orang yang menggunakan Narkotika tanpa hak atau melawan hukum. Seorang penyalahguna narkotika dan pecandu harus dijauhkan dari stigma pidana dan seharusnya diberikan perawatan. Upaya penanggulangan penyalahgunaan narkotika yang sering diabaikan oleh aparat penegak hukum di Indonesia, yaitu adanya upaya rehabilitasi. Pada saat pengguna memasuki panti rehabilitasi, masing-masing individu harus berkomitmen pada diri sendiri dan sesama anggota untuk memperbaiki dan meningkatkan mutu kehidupan di segala bidang, yaitu mental, spiritual, sosial dan jasmani, dengan demikian, hidup bersama, semangat persaudaraan, dan komitmen timbal-balik antara mereka dengan sendirinya menjadi model sekaligus metode penyembuhan bagi mereka masing-masing (Syafitri, 2013).

Oleh karena itu pecandu atau pengguna narkoba tidak harus diperlakukan seperti seorang penjahat ataupun pasien ketergantungan, akan tetapi harus diperlakukan secara normal seperti orang biasa (Vliet, 1990). Namun dalam realisasi di lapangan Pengguna/penyalahguna narkoba ini masih kerapkali diberikan pidana di dalam lapas seperti bandar maupun pengedar. Padahal seharusnya penyalahguna narkotika ini tidak dijatuhkan pidana di lapas, melainkan dijatuhi pidana alternatif untuk dilakukan rehabilitasi untuk menghilangkan kecanduan dan memulihkan mentalnya. Hal tersebut diperkuat dalam pasal 54 UU No. 35 tahun 2009 yang menyatakan bahwa "Pecandu Narkotika dan korban penyalahgunaan Narkotika wajib menjalani rehabilitasi medis dan rehabilitasi sosial." Berdasarkan fakta tersebut pemulihan bagi para narapidana yang di lapas itu menjadi sangat penting untuk dilakukan karena pada dasarnya mereka merupakan korban dari 
penyalahgunaan narkoba, yang mana perlu diberikan program pembinaan yang dapat merehabilitasi mereka untuk dapat pulih dari efek ketergantungan dari narkoba tersebut, sehingga mereka dapat kembali kedalam masyarakat dalam keadaan sehat dengan pulih dari ketergantungan narkoba dan sudah menyadari kesalahannya, sehingga hal tersebut dapat menekan angka penyalahgunaan narkoba di Indonesia dan dapat juga menekan arus peredaran narkoba di Indonesia, yang dikarenakan sedikitnya pemakai atau pengguna tersebut.

\section{METODE}

Jenis penelitian yang digunakan dalam penelitian ini adalah jenis penelitian deskriptif. Penelitian deskriptif merupakan metode penelitian yang berusaha menggambarkan dan menginterpretasi objek sesuai dengan apa adanya. Penelitian ini juga sering disebut noneksperimen, karena pada penelitian ini penelitian tidak melakukan kontrol dan manipulasi variabel penelitian. Teknik pengambilan data dilakukan dengan studi pustaka, studi dokumen, serta wawancara.

\section{HASIL DAN PEMBAHASAN}

Sebelum kita menuju kepada penjelasan tentang pelaksanaan sistem pemasyarakatan, kiranya perlu dijelaskan lagi bahwa konsepsi atas pemasyarakatan itu bukanlah sematamata hanya merumuskan tujuan dari pidana penjara, melainkan merupakan suatu sistem pembinaan, suatu metodologi dalam bidang Treatment of Offenders yang multilateral oriented dengan pendekatan yang berpusat kepada potensi-potensi yang ada baik itu ada pada individu yang bersangkutan, maupun yang ada di tengah-tengah masyarakat sebagai suatu keseluruhan atau community base treatment (Widiada Gunakarya, 1988:83). Pasal 1 Peraturan Pemerintah Republik Indonesia No. 31 Tahun 1999 tentang Pembinaan dan Pembimbingan Warga Binaan Pemasyarakatan merumuskan bahwa, pembinaan merupakan kegiatan yang meningkatkan kualitas ketaqwaan kepada Tuhan Yang Maha Esa, intelektual, sikap dan perilaku, profesional kesehatan jasmani dan juga rohani Narapidana dan Anak Didik Pemasyarakatan Pelaksanaan pembinaan terhadap para narapidana diatur di dalam Pasal 7 Peraturan Pemerintah No. 31 Tahun 1999 tentang Pembinaan dan Pembimbingan Warga Binaan Pemasyarakatan yakni merumuskan tentang pembinaan narapidana dilaksanakan melalui beberapa tahap pembinaan: tahap awal; tahap lanjutan; dan diakhiri dengan tahap akhir. Dalam Surat Edaran Direktorat Jenderal Pemasyarakatan/ Bina Tuna Warga No. KP.10.13/3/31, Pemasyarakatan sebagai Proses, maka hendaknya disalurkan dalam tahap demi tahap guna menghindari kegagalan daripada akibat-akibat lain yang tidak diinginkan. Tahapan-tahapannya sebagai berikut:

1. Hendaknya narapidana pada waktu akan datang ke Lapas dikenal dan diketahui dahulu apa kekurangan dan kelebihannya. Sebab-sebab sampai ia melakukan tindak pidana, dan lain-lain hal tentang dirinya. Dengan bahan tersebut dapat direncanakan, lalu dilakukan usaha pembinaan terhadapnya.

2. Bilamana pembinaan dari narapidana dan hubungan dengan masyarakat telah berjalan selaras selama 1/3 dari masa pidana yang sebenarnya dan menurut pendapat Dewan Pembinaan Pemasyarakatan sudah dicapai kemajuan dalam proses maka dapat dipindah ke Lapas medium security. Di tempat baru ini narapidana diberi tanggungjawab lebih besar, lebihlebih dalam tanggungjawab terhadap masyarakat luar, bersamaan pula untuk rasa harga diri, untuk mana sehingga masyarakat timbul kepercayaannya dan merubah sikapnya terhadap narapidana. 3. Jika sudah dijalani kurang lebih separuh masa pidana yang sebenarnya dan menurut Dewan Pembinaan Pemasyarakatan proses pemasyarakatan telah mencapai kemajuan yang lebih, baik mengenai narapidana maupun unsur-unsur masyarakat, maka wadah perlu diperluas, dimulai dengan usaha asimilasi narapidana pada kehidupan masyarakat luar, seperti sekolah umum, beribadah, berolahraga dan lainnya. Segala masih dalam pengawasan 
dan bimbingan petugas pemasyarakatan. 4 . Akhirnya jika sudah menjalani $2 / 3$ dari masa pidana yang sebenarnya, sedikitnya 9 bulan dapat dilepaskan pelepasan bersayarat, kalau proses berjalan dengan lancar dan baik. Pada tahap ini wadah proses pemasyarakatan berupa masyarakat luar yang luas. Hidup dan kehidupan narapidana dengan unsur dari masyarakat telah menjadi positif dan merupakan suatu kebutuhan, suatu integritas. Sebagai suatu fungsi pemasyarakatan maka Lapas bukan saja sudah berubah dalam pola pembinaan yang dilakukan sekaligus juga sudah harus mengubah orientasinya dari lembaga konsumtif menjadi lembaga produktif.

Pembinaan mental dan keterampilan yang diberikan sesuai dengan yang telah tercantum dalam Keputusan Menteri Kehakiman No. M.02.PK.04.10 Tahun 1990 tentang Pola Pembinaan Narapidana, terdiri dari Pembinaan Kepribadian dan Pembinaan Kemandirian, yaitu: Pertama, Pembinaan Kepribadian: pembinaan kesadaran untuk beragama; pembinaan berbangsa dan bernegara; pembinaan kemampuan intelektual; pembinaan kesadaran terhadap hukum; pembinaan mengintegrasikan diri dengan masyarakat. Kedua, Pembinaan Kemandirian: juga keterampilan untuk mendukung akan usaha-usaha mandiri; keterampilan untuk mendukung usaha-usaha industri; keterampilan yang dikembangkan sesuai bakat masing-masing; mendukung usaha industri atau kegiatan pertanian.

Lapas Narkotika Kelas IIA Jakarta merupakan salah satu Lapas yang menjalankan sistem pemasyarakatan, yang diperuntukan untuk membina narapidana kasus narkotika. Pak Margono selaku Kepala Seksi Bimbingan Narapidana dan Anak Didik Pemasyarakatan di Lapas Narkotika Kelas IIA Jakarta menjelaskan mengenai upaya pembinaan yang dilakukan untuk narapidana pengguna narkotika di Lapas Narkotika Kelas IIA Jakarta, yaitu: "Pelaksanaan pembinaan oleh warga binaan yang berada dalam Lembaga Pemasyarakatan Narkotika Kelas IIA Jakarta, yang keseluruhannya merupakan terpidana tindak pidana akan penyalahgunaan narkoba sama dengan pembinaan pada umumnya seperti dalam ketentuanketentuan Undang-Undang No. 12 tahun 1995 tentang Pemasyarakatan. Yang dimana tahap-tahap itu Pembinaan awal yang didahului dengan masa pengamatan, penelitian, dan pengenalan lingkungan, sejak diterima sekurang-kurangnya $1 / 3$ dari masa pidana yang sebenarnya. Pembinaan tahap kedua merupakan lanjutan pembinaan di atas $1 / 3$ sampai sekurangkurangnya $1 / 2$ dari masa pidana yang sebenarnya. Pembinaan lanjutan di atas $1 / 2$ sampai sekurang-kurangnya $2 / 3$ dari masa pidana yang sebenarnya dan sudah diperoleh kemajuan dari berbagai hal maka pembinaan akan diperluas. Kemudian pembinaan lanjutan di atas 2/3 sampai selesai masa pidananya dan jika dinilai sudah siap dikembalikan ke masyarakat maka narapidana dapat diusulkan untuk mendapatkan pembebasan bersyarat (PB) daan cuti menjelang bebas (CMB)". Lebih lanjut Pak Margono menjelaskan pendekatan yang dilakukan petugas (pembina) dalam melakukan pembinaan terhadap narapidana narkoba, yaitu: "Petugas dalam melakukan pembinaan menggunakan pendekatanpendekatan baik secara personal atau individu dan juga secara kelompok, hal ini ditujukan agar dapat meminimalisir hal-hal yang tidak diinginkan, misalnya perkelahian antar narapidana. Pembinaan yang ada dilakukan secara terencana dengan baik dan dilakukan terus-menerus sampai napi itu benar-benar memahami pembinaan yang diberikan". Pelaksanaan pembinaan oleh Warga Binaan yang berada dalam Lapas Narkotika Kelas IIA Jakarta, yang keseluruhannya merupakan terpidana tindak pidana akan penyalahgunaan narkotika sama dengan pembinaan pada umumnya seperti dalam ketentuan ketentuan Undang-Undang No. 12 tahun 1995 tentang Pemasyarakatan. Namun ada yang berbeda yaitu, pembinaan di Lapas narkotika lebih memperhatikan pada tingkat kesehatan Warga Binaannya, dimana para Warga Binaan yang mayoritas pengguna narkotika sangatlah rentan terhadap penyakit. Serta membangun mental mereka agar mau menjauhi narkotika. Berdasarkan penuturan Agus sebagai Pembina di Lapas Narkotika Kelas IIA Jakarta, pembinaan bagi narapidana pengguna narkotika itu: 
"untuk narapidana narkoba terdapat pembinaan yaitu Therapeutic Community (TC) atau rehabilitasi khusus bagi narapidana narkoba, yang dilaksanakan oleh Lapas dan BNN". Pembinaan dengan Therapeutic Community (TC) yang dilaksanakan oleh Lapas dan BNN ini merupakan salah satu bentuk kerjasama yang dilakukan oleh Lapas Narkotika Kelas IIA Jakarta dalam melakukan pembinaan terhadap narapidana narkotika. Berdasarkan penjelasan Agus (pembina) bentuk kerjasama yang dilakukan oleh Lapas dengan pihak BNN, yaitu : Kerjasama pihak Lapas dengan BNN dalam melaksanakan TC atau rehabilitasi bagi narapidana narkoba. Dari pihak BNN mendatangkan konselor. Pihak konselor itulah yang melakukan rehabilitasi dan yang mengurus masalah kebutuhan-kebutuhan selama pelaksanaan rehabilitasi itu dari pihak Lapas. (Therapeutic Community) TC adalah suatu metode rehabilitasi sosial yang ditujukan kepada korban penyalahguna narkoba, yang merupakan sebuah keluarga terdiri dari atas orang-orang yang mempunyai masalah yang sama dan memiliki tujuan yang sama, yaitu untuk menolong diri sendiri dan sesama yang dipimpin oleh seseorang dari mereka, sehingga terjadi perubahan tingkah laku dari negatif kearah tingkah laku yang positif. Proses pemulihan merupakan proses yang harus dijalani seumur hidup seorang pecandu (long life process). Proses pemulihan itu sendiri melewati enam periode yaitu

1. Periode pra perawatan (pre treatment) pecandu akan mencoba dengan berbagai cara untuk mengatasi proses ketergantungan fisik dan belajar untuk mengakui bahwa dia tidak bisa mengontrol perilaku penggunaan zatnya.

2. Periode stabilitasi (stabilization) pecandu akan belajar untuk tidak menggunakan zat, membuat kondisi fisik lebih stabil dari gejala putus zat, belajar untuk mengatasi tekanan sosial dan masalah.

3. Periode pemulihan awal (early recovery) pecandu pada tahap ini membangun pola pikir mengapa ia tidak dapat lagi menggunakan zat adiktif dan mulai untuk membangun system nilai personal.

4. Periode pemulihan tengah (middle recovery) pecandu memasuki masa transisi dimana ia mengalami hambatan dalam keterampilan bersosialisasi, namun ia sampai pada periode konsolidasi di dirinya.

5. Periode pemulihan lanjut (late recovery) pada saat ini diharapkan pecandu sudah memiliki kesadaran spiritual, memiliki prinsip hidup yang pasti menemukan keinginan serta semangat hidup.

6. Periode pemeliharaan (maintenance) pecandu diharapkan mempertahankan kondisi bebas zatnya dan mencoba hidup kembali sebagimana masyarakat pada umumnya dengan sistem hidup mereka yang baru.

Indikator keberhasilan meliputi dua aspek, yaitu indikator keberhasilan program dan indikator keberhasilan residen. Indikator yang dapat digunakan untuk menilai program rehabilitasi ini berhasil atau gagal adalah:

1. Angka drop out pada setiap tahapan

2. Angka residen yang kabur

3. Angka kekambuhan

4. Adanya peningkatan status kehidupan residen yang lebih baik selama dan setelah mengikuti program yang dinilai dari pelaksanaan pekerjaan, sekolah dan perilaku sehari-hari dilingkungan keluarga maupun di lingkungan social lainnya

Residen yang memenuhi kriteria diatas akan di wisuda dan disebut sebagai residen yang telah pulih total (whole recovery person). Melalui tahap wawancara berhadapan dengan beberapa penulis dari: psikolog, konselor, dan pekerja social, serta dilakukan pemeriksaan silang dengan teman (peer group) menggunakan daftar pertanyaan. Selain pembinaan dengan metode TC, di Lapas juga dilaksanakan pembinaan kerohanian untuk dapat merubah narapidana menjadi manusia yang 
lebih baik dari sebelumnya. Berdasarkan keterangan dari Pak Margono (Kasi Bimnadik), pembinaan keagamaan yang dilakukan di Lapas selain diberikan oleh petugas (pembina), lapas juga menjalin kerjasama dengan 4 orang ustasd dari luar untuk membantu dalam melakukan pembinaan. Pembinaan keagamaan yang diberikan di Lapas Narkotika Kelas IIA Jakarta itu berupa, pemberian materi dasardasar pokok ajaran Islam yang wajib dilakukan oleh setiap umat Islam seperti tuntutan mandi, wudhu, shalat, puasa, dan lain sebagainya serta pengajaran terkait baca dan tulis Al-Qur'an.

Selain itu dalam rangka mengefektifkan materi pembinaan kegamaan yang ada tersebut, pembina pemasyarakatan memberikan materi tambahan, berupa: Pertama, pembinaan moralitas keagamaan, maka bimbingan akhlak menjadi sangat penting untuk diberikan. Dalam pembinaan akhlak ini, mereka diajarkan tentang keteladanan rasul SAW seperti sifat-sifat rasul, kemudian akhlak beliau, dan lain-lain. Yang paling peting disini adalah bagaimana mereka dapat mengimplementasikan apa yang telah mereka pelajari di dalam kehidupan mereka sehari-hari dan mengarahkan perilaku mereka agar sesuai dengan kaidah agama. Kedua, memberikan sedikit tambahan materi berupa pembinaan aqidah karena melalui pembinaan aqidah para narapidana diajarkan bahwa apa yang ada dalam kehidupan sudah diatur dan menyadari bahwa manusia diciptakan semata-mata untuk menyembah kepada-Nya. Dengan diberikan pemahaman tentang agama secara menyeluruh maka dengan sendirinya apapun yang dilakukannya akan dikembalikannya pada aturan agama. Pembinaan keagamaan yang diberikan oleh Lapas Narkotika Kelas IIA Jakarta ini, menurut salah satu narapidana merupakan salah satu pembinaan yang sangat bermanfaat dan berhasil mewujudkan salah satu prinsip pemasyarakatan, dimana negara tidak berhak menjadikan narapidana menjadi lebih buruk daripada sebelum ia masuk kedalam Lapas, hal ini diakui sendiri oleh Asep (Narapidana) tersebut. "Pembinaan kegamaan sangat bermanfaat bagi saya, sebelum masuk sini (Lapas) saya tidak paham mengenai agama, setelah dapat bimbingan agama menjadi bertambah pemahaman saya tentang agama. Disini juga diajarkan tentang baca Al-Quran, saya sekarang sudah bisa sedikit mengaji, padahal dulu saya tidak bisa mengaji".

\section{Hambatan dalam Pelaksanaan Pembinaan di Lembaga Pemasyarakatan Narkotika Kelas IIA Jakarta}

Setiap Lapas Narkotika pasti akan mengahadapi suatu hambatan atau kendala yang dapat menggangu jalannya proses pembinaan yang dilaksanakan di dalam Lapas tersebut. Demikian halnya juga dengan Lapas Narkotika Kelas IIA Jakarta ini mempunyai hambatan atau kendala, baik dari dalam maupun dari luar Lapas, pada waktu melaksanakan proses pembinaannya terhadap narapidana. Dalam melaksanakan suatu pembinaan, tidaklah terlepas dari hambatan-hambatan yang ada. Disini mencoba untuk mengklasifikasikan hambatan dalam proses pembinaan yang didapat dari wawancara, hambatan tersebut antara lain yakni: 1. Kedisiplinan dan Motivasi warga binaan yang rendah, Agus (Pembina) menyatakan bahwa "Ketika sudah dimulainya pembinaan, terdapat beberapa narapidana narkoba yang masih berada didalam kamar menunggu sampai pembimbing selesai memberikan bimbingannya itupun hanya ada beberapa orang seperti itu", hal ini juga dikeluhkan oleh Anton (Pembina) yang menyatakan "Kendala yang dihadapi saat memberikan pembinaan adalah dari segi waktu (tidak on time), masih ada yang buta AlQu'ran, kemudian kurangnya motivasi dan kesadaran dari diri pribadi narapidana khususnya narapidana narkoba". Dan hal ini juga diakui oleh Asep (Narapidana) bahwa "hambatan yang paling susah itu memotivasi diri sendiri agar mau berubah sebelum kita memotivasi teman-teman yang lain". 2. Koordinasi dengan pihak BNN yang agak sulit, Agus (pembina) menyatakan bahwa "Koordinasi dengan pihak BBN agak sulit, biasanya via telpon. Terus pendanaanya berada BNN, sementara yang melaksanakannya dari pihak Lapas 
dan BNN terus yang mengurus masalah kebutuhan-kebutuhan selama pelaksanaan rehabilitasi itu Lapas". 3. Masih beredarnya narkoba di dalam Lapas, Anton (Pembina) menyatakan bahwa "Untuk di Lapas sendiri kita tidak bisa menjamin mereka tidak menggunakan kembali narkoba, karena banyaknya pengunjungpengunjung yang terkadang mengelabui petugas dengan membawa narkoba disembunyikan. Terkadang mereka lolos dari pemeriksaan petugas, hal ini yang menjadi kendala kami".

\section{PENUTUP}

Pada dasarnya setiap pemerintah daerah di Indonesia dipimpin oleh kepala daerah yang dipilih secara demokratis. Kepala Pemerintah Daerah Provinsi, Kabupaten dan Kota dibantu oleh satu orang wakil kepala daerah, untuk provinsi disebut wakil Gubernur, untuk kabupaten disebut wakil bupati dan untuk kota disebut wakil wali kota.

Implikasi dari pemberlakuan Undang-Undang No.23 Tahun 2014 tentang Pemerintahan daerah terhadap penyelenggaraan penataan ruang lainnya adalah proses evaluasi Rancangan Perda Rencana Tata Ruang Provinsi/Kabupaten/Kota yang menjadi lebih panjang karena dalam proses evaluasi, Menteri Dalam Negeri harus berkoordinasi dengan Menteri Agraria dan Tata Ruang. Dan begitu pula sebaliknya penerapan Undangundang Nomor 26 Tahun 2007 tentang Penataan ruang sangat penting dalam pemerintahan daerah agar terwujudnya penataan ruang yang terpadu dan kemanfaatan untuk setiap daerah yang ada di Indonesia

Dari beberapa pasal-pasal yang telah dijelaskan diatas mengenai Undang-Undang Nomor 26 Tahun 2007 tentang Penataan Ruang yang dapat disimpulkan bahwa penataan ruang yang baik pada pemerintahan daerah dapat diwujudkan apabila pemerintahan daerah mengikuti konstitusi yang ada dan masyarakat diijinkan berperan aktif dalam upaya penataan ruang di dalam pemerintahan daerah.

\section{DAFTAR PUSTAKA}

\section{Peraturan Perundang-undangan}

Undang-Undang Nomor 23 Tahun 2004 Tentang Pemerintahan Daerah

Undang-Undang Nomor 26 Tahun 2007 Tentang Penataan Ruang

\section{Buku}

Erwin, Muhamad Pendidikan Kewarganegaraan Republik Indonesia, Bandung: PT Refika Aditama. 2017

Salim, Agus, Pemerintahan Daerah Kajian Politik dan Hukum, Ghalia Indonesia, Jakarta, 2004

\section{Artikel Jurnal}

Dahfid Ari, "Kewenangan Pemerintah Daerah dalam Penataan Ruang Setelah Berlakunya UU No.23 Tahun 2014". Jurnal Hukum Maranatha Christian University. Vol.9 No.1, November 2017

Haryanti Amelia, Sistem Pemerintahan Daerah Tangerang Selatan : UNPAM Press. 11 Juli 2019

I Wayan Parsa, dkk, Laporan Akhir Tim Pengkajian Hukum tentang Penegakan Hukum Penataan Ruang Dalam Kerangka Otonomi Daerah, Badan Pembinaan Hukum Nasional, Tahun 2014.

Michael Barama, "Pelaksanaan Pemerintahan Daerah Dan Penerapan Sanksi Administrasi Dalam Peraturan Daerah". Jurnal Hukum Unsrat. Vol.22 No.5 Januari 2016 
Sirajuddin. (2017). Desain Pengujian Peraturan Perundang-undangan secara Integratif di bawah Mahkamah Kobstitusi . Arena Hukum.

\section{Website}

Achmad Nasrudin, Teka-teki Penyebab Banjir Besar di Kalimantan Selatan, Diambil21Januari2021,Darihttps://nasional.kompas.com/read/2021/01/21/085359 51/teka-teki-penyebab-banjir-besar-di-kalimantan-selatan?page=all

Sovia Hasanah, Arti dan Maksud Tugas Pembantuan Pemerintah, Ditulis 6 Maret 2017, Dari https://www.hukumonline.com/klinik/detail/ulasan/lt58b4dd94d9b04/arti-danmaksud-tugas-pembantuan-pemerintah/ 